\title{
A ‘NEW’ ROMAN TEMPORARY CAMP IN PARÂNG MOUNTAINS
}

\author{
Eugen S. Teodor, Aurora Peţan, Alexandru Hegyi
}

\begin{abstract}
A new Roman camp was documented - mainly for its topographical features - far away from any known camp from Şureanu Mountains. It has a typical size of the encampments from around Sarmizegetusa Regia, 5 hectares, as no one reaches a full-size legionary camp. Having tituli and being made of two parts separated by a palisade, it finds also analogies in the region (as Comărnicel 1). What is really outstanding at the encampment from Cracul Găurilor is the steep slope on which it is standing with more than half of its surface.

Its location raises the problem of new routes driving to the Dacian capital. One of them could have its departure point at the lower end of the Jiu Gorges, at the Vârtop fort. Another - less plausible but still possible - would start on the Middle Olt River, at Buridava.
\end{abstract}

Rezumat: Un „nou” castru roman de marş în Munţii Parâng

Un castru roman de marş, aflat departe de oricare obiectiv similar din zona Munţilor Şureanu, a fost documentat, în special pentru caracteristicile sale topografice. Dimensiunile sale sunt tipice pentru taberele romane din jurul Samizegetuzei Regia, respectiv 5 hectare, fiindcă nici un astfel de obiectiv nu putea adăposti o legiune completă. Având porţi cu tituli şi fiind compus din două părţi separate de o palisadă, el îşi găseşte analogii relative în regiune, cum ar fi castrul Comărnicel 1 . Ceea ce este neobişnuit şi frapant pentru castrul de la Cracul Găurilor este panta aspră pe care este construită mai mult de jumătate din suprafaţa sa.

Poziţia sa geografică ridică problema unor noi rute romane având ca ţintă capitala dacică. Una dintre ele ar avea ca punct de plecare castrul de la Vârtop, la ieşirea din Defileul Jiului; cealaltă, mai puţin plauzibilă, dar nu imposibilă, ar avea ca staţie de pornire castrul de la Buridava, de la Oltul de mijloc.

Key words: Roman temporary encampment; vexillation camp; Dacian wars; Parâng Mountains; high slopes

Cuvinte cheie: castru roman de marş; castru de vexilaţie; războaiele dacice; Munţii Parâng; pante abrupte

\section{INTRODUCTION}

The so called 'Dacian Mountains', guarding the capital Sarmizegetusa Regia, have still many hidden landscapes, although under the scrutiny of the historians (and treasure hunters) from more than 200 years. This was recently proved by British archaeologists, benefiting a LiDAR cover of the area from 2011, made at BBC request. ${ }^{1}$ This recent contribution showed the existence of some Roman temporary camps nearby the Dacian regal seat, at Dealul Şesului and Cornu Pietrii (Figure 1). ${ }^{2}$ The great picture is still in progress, as some of them are not properly published (Bătrâna and Târsa, for instance), ${ }^{3}$ not known by the

\footnotetext{
${ }^{1}$ Olteanu, Hanson 2017.

${ }^{2}$ Olteanu, Hanson 2017, 435-438.

${ }^{3}$ The encampment from Bătrâna is also known from several years, being visible on Google Earth. For Târsa there
} 
public (Ocoliş), or require certain re-evaluations (Muncel, Prisaca, Poiana Omului, Ponorici). ${ }^{4}$

Some of the Roman camps from the mountains are still known only from a small circle of connoisseurs, being previously mentioned in the 'grey' literature. This is the case for Cracul Găurilor from Parâng Mountains, mentioned first (?) seven years ago. ${ }^{5}$ Its remote position made us delay several years our intention of documenting it better. In 2018 we have succeeded finally to make two separate expeditions in Northern Parâng (August and November), at the altitude of $1900 \mathrm{~m}$, where the camp lays. In the November mission it was used a DJI Phantom 4 PRO drone, collecting 119 snapshots, processed with Agisoft Professional from Photoscan. Came up 9.389.038 referenced points interpolated to acquire a terrain model having a resolution of $23.5 \mathrm{~cm} /$ pixels and produce an orthophoto with a resolution of 11.7 $\mathrm{cm} /$ pixel. $^{6}$

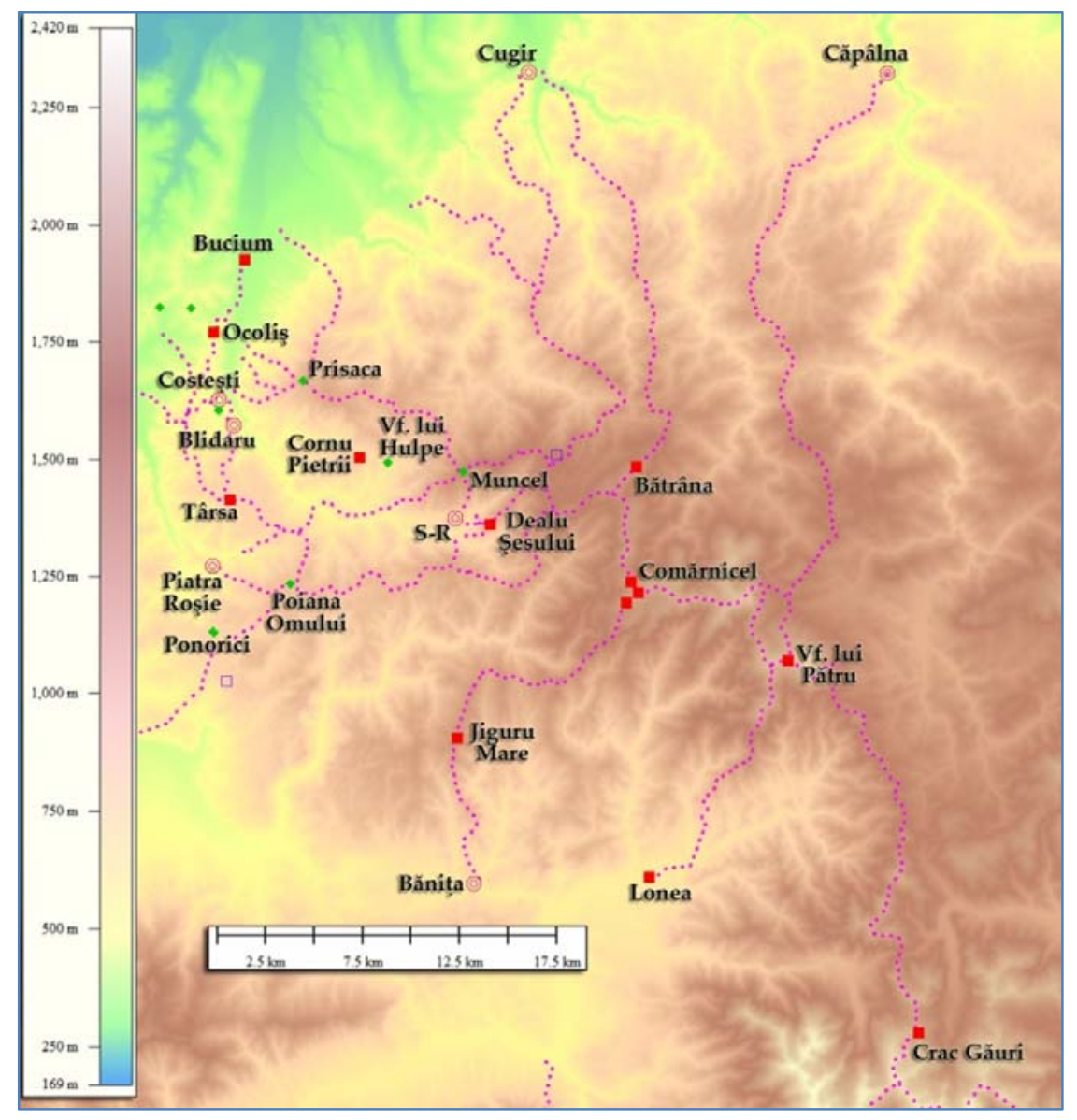

Figure 1. Șureanu Mountains and the main military objectives in the time of the Trajan's wars. SRTM-30 (2018), UTM projection.

Legend: red squares Roman camps; double red circles - Dacian stone strongholds; green diamonds - other Dacian hillforts; empty black squares - other possible earthworks; magenta broken lines - ridge roads across mountains.

are several archaeological renditions, older (Daicoviciu, Ferenczi 1951, 48-49) and newer (Teodor, Pețan, Berzovan 2013, esp. 20-28). For Târsa we are going to publish new data, more accurate, taking advantage of the new technologies.

${ }^{4}$ For Muncel we already published a recent point of view (Teodor, Pețan, Hegyi 2018). For Prisaca see mainly Daicoviciu, Ferenczi 1951, 46, which is a short but fair description of the facts; Ferenczi 1983, 381, for a 'consecration' of it as a 'Roman camp' (due to its... shape); against all odds, it is still considered a Roman camp (Stefan 2005, 608). For Poiana Omului see again Teodor, Pețan, Berzovan 2013 a, esp. 4-11. For Ponorici there is a considerable literature but almost no research (see Teodor, Pețan, Berzovan 2013 an for an account of the problem and its literature).

${ }^{5}$ Oltean 2012, 512-519. The author named the place 'Coasta lui Rus Mică' from the name of the peak located immediately west of the camp, name taken from an unknown map (România Digitală - Garmin?). The connection made between the fort from Bumbești-Gară and the encampment from the Parâng is wrong, due to the differences in chronology, but the proposed route over the Moldivișu Peak is alright.

${ }^{6}$ As the mission ended around 4 p.m., the processed image is half in the full light, but half in the shadow, as mountain peaks over $2300 \mathrm{~m}$ are located closely southwest. It is good for study, but not that good for publication. 


\section{DESCRIPTION OF THE CAMP}

The camp is about 5 hectares and, except its northern third, it is standing on a strong slope (Figure 2); therefore, its rampart is visible only in its upper part. ${ }^{7}$ For a change, the ditch is somehow better preserved, being visible almost all around, and we will give the measured dimensions along it: maximum length is $306 \mathrm{~m}$; the width near the southern corners is $298 \mathrm{~m}$, but near the northern corners only $275 \mathrm{~m}$, having thus rather a trapeze shape. Everywhere the distance between the rampart and the ditch can be measured it is about $2.5 \mathrm{~m}$; therefore, from the dimensions given above one will extract $5 \mathrm{~m}$ for each. The northern side, which is also the shortest, is not straight, but with a protruded shape where the gate was done, about $17 \mathrm{~m}$ forward.

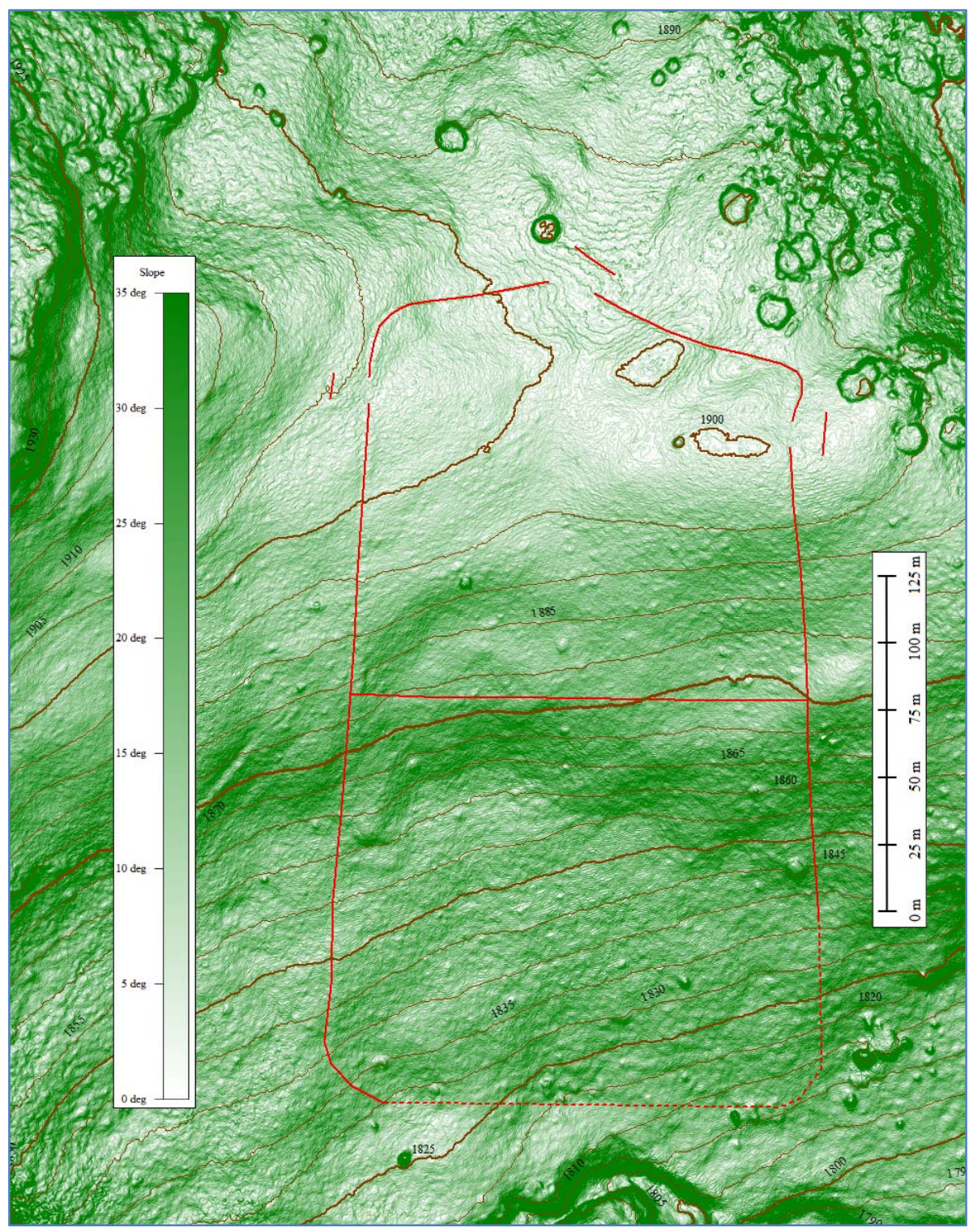

Figure 2. Plan of the encampment at Cracul Găurilor. Terrain-model at $0.23 \mathrm{~m}$ resolution, rendered as slope shadow. Contour lines added for each $5 \mathrm{~m}$ interval. Legend: red lines - visible contour of the ditches; broken lines - lines not visible on the terrain model.

\footnotetext{
${ }^{7}$ See also Figure 6. As we have mentioned several times before, the conservation status of the ramparts and ditches is directly connected with the slope value (see, for instance, Teodor 2018, 334-335).
} 
There are visible three gates, all having a titulus. The main entrance is on the northern side, facing enemy, having a (small) ditch dug $12.4 \mathrm{~m}$ forward. The rampart of titulus is not visible and the ditch itself is barely visible on the terrain model (a DEM with a resolution of $23 \mathrm{~cm}$ ), but it is clear on many snapshots (both from the air and from the ground), due to the late afternoon light (Figure 3). The reason why the northern side is angular we can only guess, and that would be the Romans were expecting uninvited guests. The fear of a northern attack is clear looking at the other two visible gates: just around the corner on both eastern and western sides; this way a large part of the expeditionary troop could intervene promptly against the attackers from the north.

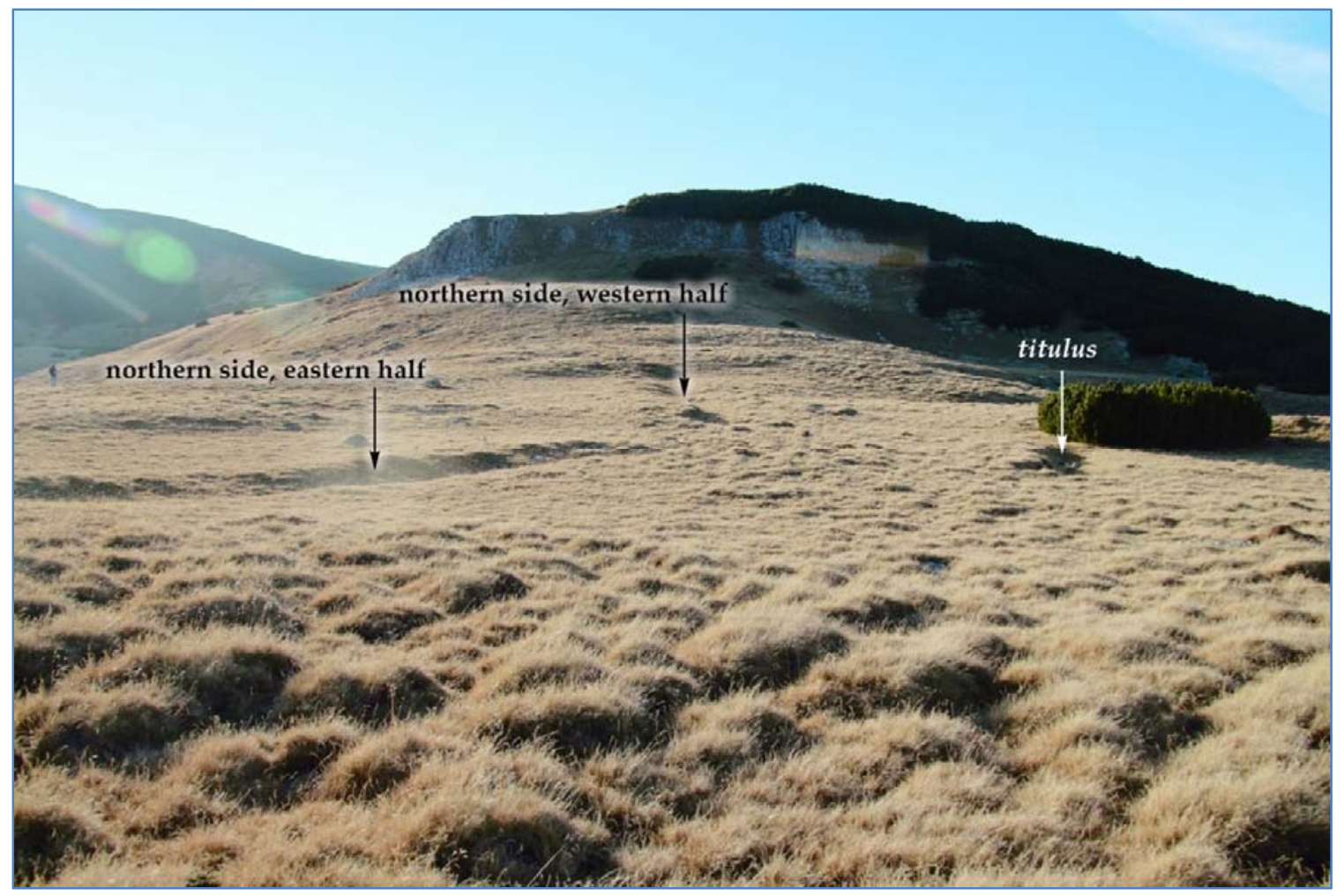

Figure 3.

The northern end of the camp. Snapshot taken from northeast, showing fortification system.

The western titulus - near the north-western corner - is $11 \mathrm{~m}$ long, preserving a short rampart, about 30 $\mathrm{cm}$ in height, $3.5 \mathrm{~m}$ wide, the ditch having similar dimensions ( $11 \mathrm{~m}$ long, $0.25 \mathrm{~m}$ deep, $3.3 \mathrm{~m}$ wide). The opposite gate, near the north-eastern corner, seems greater or - more likely - it is better preserved. Titulus is $15.8 \mathrm{~m}$ long, but the profile is very week (just a few $\mathrm{cm}$ for both the ditch and the rampart, see Figure 4). The gate is apparently closed also by a ditch crossing all the gate width, but this is more likely what waters have dug, not the Romans.

No other entrance is visible, but of course they should be more. As stated before, the camp is divided in two similar halves, and the southern enclosure has no obvious gate. An opening on the northern side is unlikely, due to the harsh slope; similarly, a gate towards east would go pretty much nowhere, because a deep valley is following (heading the Lotru River springs). On the western side the ditch is continuous and no titulus (or clavicula) can be guessed. The southern side of the camp is not preserved; it can be yet drawn due to the south-western rounded corner. ${ }^{8}$ An opening here seems compulsive, as it is flanking the stream of water, the only source in the area.

\footnotetext{
${ }^{8}$ The orthophoto shows supplementary parts of the southern ditch, mainly in its western and central parts.
} 

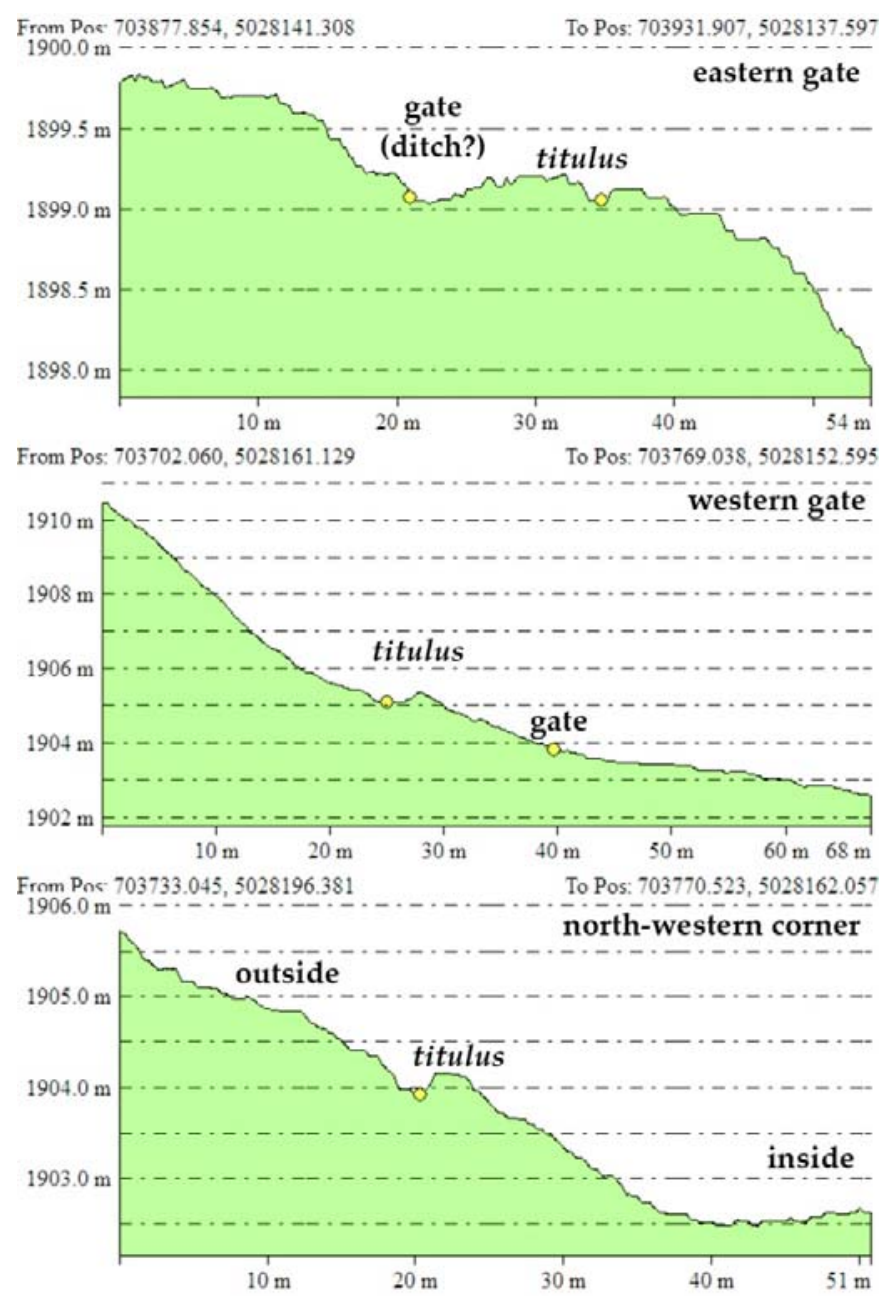

From Pos: $703807.819,5028195.949$

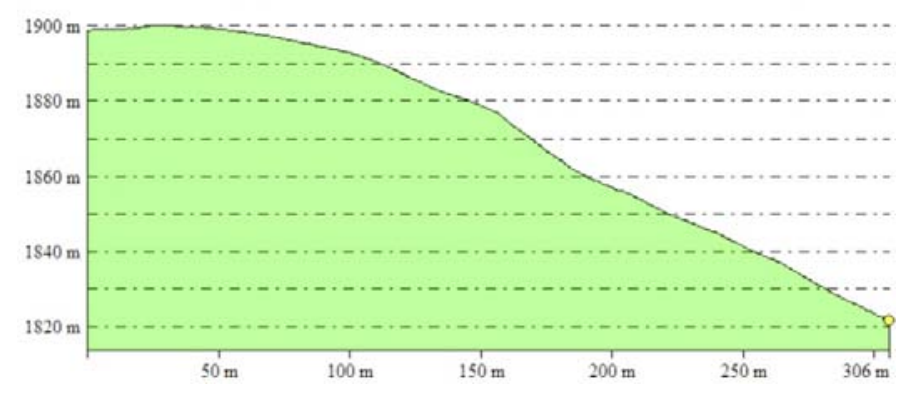

Figure 4. Topographical sections through the fortification system, showing the conservation status, in order the eastern and western gates and the north-western corner. UTM coordinates.
Figure 5. Longitudinal topographical section through the camp Cracul Găurilor, from north to south. UTM coordinates.

The main issue connected with the camp at Cracul Găurilor is the strong slope on which it was laid. Looking at a section crossing longitudinal the enclosure, one will find the next (see Figures 5 and 6):

- $\quad 32 \mathrm{~m}$ at the northern end the terrain has a small northern tilt (about $2^{\circ}$ );

- the next $74 \mathrm{~m}$ southward the slope is changing towards south, with moderate values (average $6^{\circ}$ );

- the next $57 \mathrm{~m}$ make the southern third of the northern enclosure, for which the slope turns steep $\left(16^{\circ}\right.$ as average);

- the northern section of the southern enclosure, $35 \mathrm{~m}$ long, is the steepest, having a slope of $28^{\circ}$, on which is difficult to stand;

- the middle and southern parts of the southern enclosure (108 $\mathrm{m}$ in length) are pretty much the same, having an average tilt of almost $19^{\circ}$. 


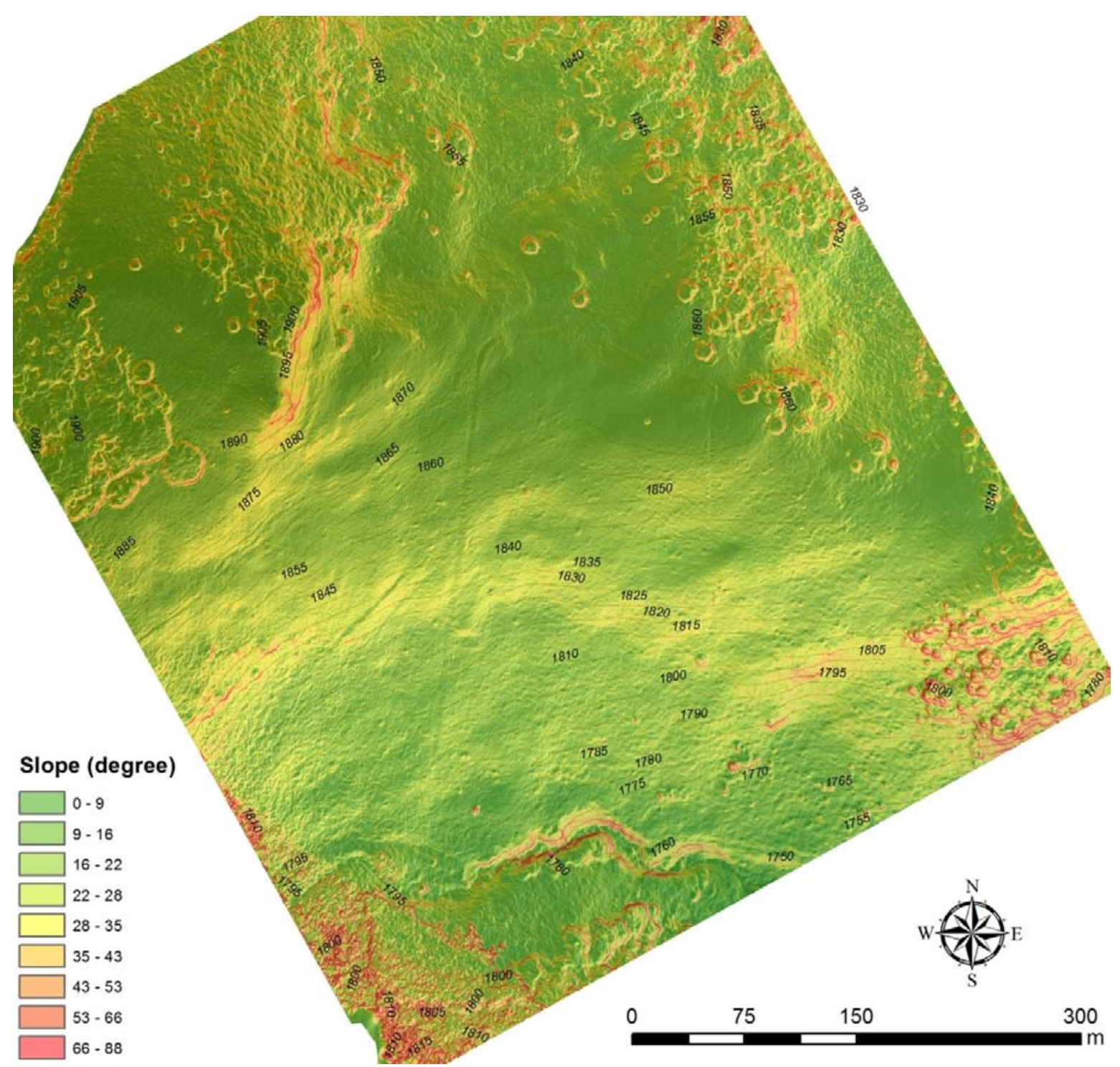

Figure 6. Slopes on the encampment and around.

Even more interesting, standing on a strong slope was a deliberate option. The next $300 \mathrm{~m}$ north of the camp the average tilt (northward) has $9^{\circ}$, which is far better than inside the camp. The situation recalls the rule spelled by antique historians to avoid a position from which the camp can be surveyed by the enemy. ${ }^{9}$ True enough, $700 \mathrm{~m}$ west of the camp there is a mountain peak raising $50 \mathrm{~m}$ above the encampment, but that one is steep and far from the normal lines of communication; more, it is likely that the Roman scouts took that position in care. The only place allowing a survey of the camp from far, Mount Ciobanul (the Shepard), $1944 \mathrm{~m}$ in height, is located $2 \mathrm{~km}$ northward. The photo from the Figure 7 is taken exactly from that place (with a strong zoom, of course), proving that there were visible only the first $30 \mathrm{~m}$ or so from the length of the camp, or, better, only the palisade. We cannot know if the Dacians were around, so far away from their permanent bases, but we can suppose that the Roman commander was worried about. The unusual shape of the front side - probably supposed to break the line of attack and the odd location of the side gates are suggesting the same.

\footnotetext{
${ }^{9}$ Campbell 2017, 71, citing Hyginus ('a hill over which the enemy could arrive or view what is going on in the camp should not dominate the camp').
} 


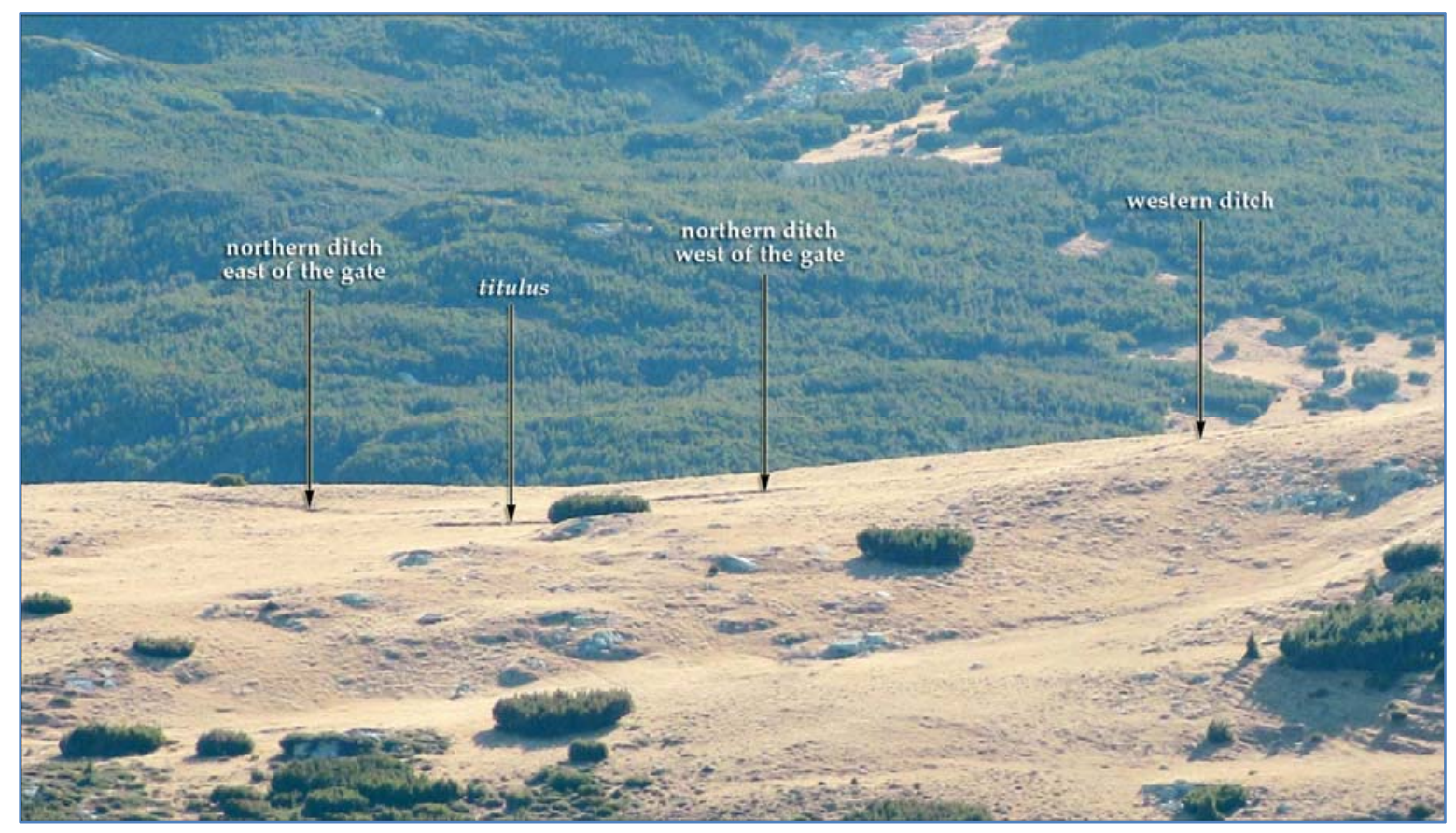

Figure 7. Photo taken from the Mount Ciobanu against the front side of the camp Cracul Găurilor.

Although Roman encampments with 'annexes' are known, including in this area (as the camp no. 1 from Comărnicel), ${ }^{10}$ the analogy should be taken carefully. Camp no. 1 from Comărnicel has another orientation, but due to the known location of the gates we can say that the 'annex' was attached also in the rear side. The main encampment is $236 \times 205 \mathrm{~m},{ }^{11}$ having attached a segment on the length, $78 \mathrm{~m}$ long. The two parts, the main camp and the 'annex' are far from even, the main encampment being three times longer, but some of the story told for Cracul Găurilor is similar. Comărnicel 1 is made around a top mountain, therefore its real size cannot be seen no matter the location of the viewer. The front half of the camp is tilt towards southwest, on a mild slope $\left(3.2^{\circ}\right.$ in average). The rear half is completely different, having much steeper slopes, with an average tilt of $8^{\circ}$, but the annex is worst, as the northern half has a slope of $16.5^{\circ}$ (Figure 8). ${ }^{12}$ Due to the similitudes of the rear annexes from Comarnicel and Cracul Găurilor, we would say that they did not serve for containing tents, but burden animals for logistics. Even more interesting, the orientation is suggesting that the troops housed there were coming from Vârful lui Pătru, possibly on the same route from Cracul Găurilor. For a change, the militaries from the camp Comărnicel 2, located less than $500 \mathrm{~m}$ southwest, were coming from Jiguru Mare. ${ }^{13}$

The name of the camp, Cracul Gărilor (or, on short, Crac-Găuri), is taken from the military map from 1980 s, the place name being written on the exact spot. ${ }^{14}$ From an administrative point of view, it is located very close to the border between the counties Hunedoara (westward) and Vâlcea (eastward), standing in Vâlcea County, within the territory of Voineasa commune.

\footnotetext{
${ }^{10}$ Stefan 2005, 299-307, with plenty of aerial images, plans and connected literature.

${ }^{11}$ Measurements on the military orthophotos (2012).

${ }^{12}$ The plan measurements for Comărnicel were performed using the military orthophotos (edition 2012); the slope is calculated on Alos Palsar terrain model (resolution $12.5 \mathrm{~m}$ ).

13 The name could be found in literature in this form or with small orthographic variations (like Jigur or Jigoru Mare), all encountered also in drivers maps. The localisation proposed at Jiguru Mic (or Jigurel) by Olteanu and Hanson (2017, 433-345) is wrong because Jigurel (diminutive, meaning the Small Jigoru) is another mountain, located over two km away from the main peak, Jiguru Mare, where the Roman camp stands (anybody can check it on Google Earth). The portal of the official national agency for maps and topography uses the form 'Jiguru Mare' (https://geoportal.ancpi.ro/geoportal/viewer/index.html).

${ }^{14}$ It is also present on the official map of Romania of our days, referring to the strong slope from the eastern side of the fort, see https://geoportal.ancpi.ro/geoportal/viewer/index.html.
} 


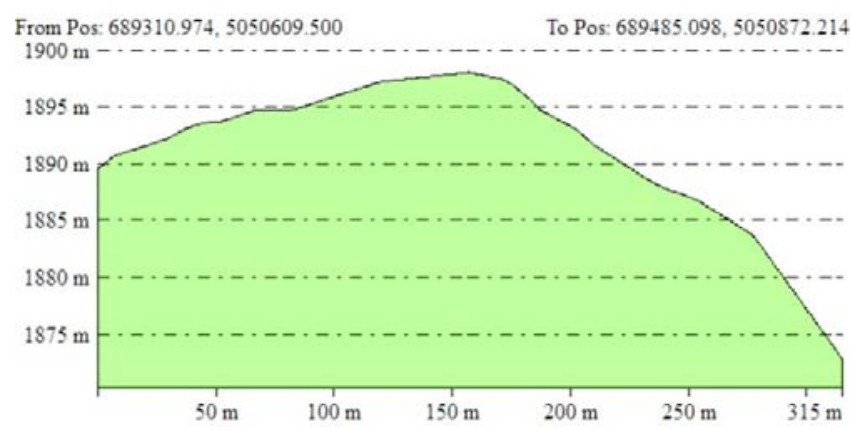

Figure 8. Longitudinal topographical section through the camp Comărnicel 1, from southwest (front) to northeast (back). UTM coordinates, Alos Palsar terrain model (12.5 $m$ resolution).

\section{THE ROLE OF THE CAMP AT CRACUL GĂURILOR IN THE DACIAN WARS}

When we learned about the camp from Parâng Mountains we were a bit surprised. It is so far from the Dacian capital and supposes such a long and hard journey... On the other hand, the piece of information was compatible with the general observation that Romans have invaded Șureanu Mountains not on two or three columns, as usually historians say, ${ }^{15}$ but on much many (at least seven). The strategical idea, simple as it is - to put a moderate pressure on very many different points from the mountainous landscape proved deadly, making Dacians to split their limited military strength in too many parts. The many bottlenecks of the communication lines were crossed shifting the places were pressure was on. This issue will not be discussed here in detail.

The existence of the camp at Cracul Găurilor explains and old know fact, but never understood before: outside the Jiu gorges we know two early Roman permanent bases: Pleșa $(234 \times 156 \mathrm{~m})^{16}$ west of the Jiu River and Vârtop (126 x $114 \mathrm{~m}){ }^{17}$ east of the river (Figure 9). As the gorges were not usable, ${ }^{18}$ being ready for traffic only in the $19^{\text {th }}$ century, both forts should have had a function connected with the wars. Pleșa is standing just at the southern end of the Pass Vâlcan (sometimes written 'Vulcan'), the main route heading the Jiu Depression for millennia. As for the fort at Vârtop, it apparently had no function; now it has, being the departure point for the journey over Parâng Mountains.

In order to have an evaluation of the difficulties faced by the Roman army approaching the Dacian Mountains (today Şureanu) we have made Table 1. Before commenting the numbers, let us see first what the table contains. On the first two columns there are noted routes through the mountains, containing known camps or relevant landmarks and the ridge routes (noted 'crest'), the last needed for an intermediary calculation on multiple routes.

Under the label 'ascending' one can see four columns, displaying the next:

- total amount of meters to ascend, along the route; ${ }^{19}$

- length of the ascending route $(\mathrm{km})$, on the $3 \mathrm{D}$ path;

- average declivity of the ascending route (percent);

- estimated hours needed to walk the route.

\footnotetext{
${ }^{15}$ E.g. Petolescu 2010, 137. See also Glodariu 2000 for a brief presentation of the Roman army operations in the area of Şureanu Mountains, named there 'Orăştie Mountains', as the whole Cluj-Napoca school does.

${ }^{16}$ Rendered as 'Porceni' by Al. Stefan (2005, 317-321).

${ }^{17}$ Vlădescu 1983, 73-74; Gudea 1997, cat. 93-94.

18 Stefan 2005, 573.

${ }^{19}$ This is not the altimetric difference between the departure point and the finish, but all ascending parts of the track, calculated by the GIS software, within the report Paths Details under Path Profile (in Global Mapper). The length and declivity are given the same.
} 
Table 1. Routes in Parâng Mountains and eastern Șureanu Mountains

\begin{tabular}{|c|c|c|c|c|c|c|c|c|c|c|c|}
\hline \multirow[b]{2}{*}{ from } & \multirow[b]{2}{*}{ to } & \multicolumn{4}{|c|}{ ascending } & \multicolumn{4}{|c|}{ descending } & \multicolumn{2}{|c|}{ total } \\
\hline & & $\mathrm{m}$ & $\begin{array}{c}\mathrm{L} \\
\mathrm{km}\end{array}$ & $\begin{array}{c}\text { decl. } \\
\%\end{array}$ & hours & $\mathrm{m}$ & $\begin{array}{c}\mathrm{L} \\
\mathrm{km}\end{array}$ & $\begin{array}{c}\text { decl. } \\
\%\end{array}$ & hours & hours & days \\
\hline Vârtop & $\begin{array}{l}\text { Cracul } \\
\text { Găurilor }\end{array}$ & 2928 & 23.30 & 12.57 & 10.02 & 1341 & 12.26 & 10.94 & 4.46 & 14.92 & 2 \\
\hline $\begin{array}{l}\text { Cracul } \\
\text { Găurilor }\end{array}$ & $\begin{array}{l}\text { Vârful lui } \\
\text { Pătru }\end{array}$ & 1639 & 13.72 & 11.95 & 21.63 & 1549 & 13.59 & 11.40 & 5.04 & 27.47 & 3 \\
\hline Lonea & $\begin{array}{l}\text { Vârful lui } \\
\text { Pătru }\end{array}$ & 1715 & 11.64 & 14.73 & 12.87 & 423 & 4.68 & 9.04 & 1.58 & 14.88 & 2 \\
\hline $\begin{array}{l}\text { Vf. lui } \\
\text { Pătru }\end{array}$ & $\begin{array}{l}\text { Comăr- } \\
\text { nicel }\end{array}$ & 576 & 5.18 & 11.11 & 7.64 & 671 & 6.60 & 10.17 & 2.33 & 10.26 & 1 \\
\hline Bănița & $\begin{array}{l}\text { Jiguru } \\
\text { Mare }\end{array}$ & 931 & 6.37 & 14.61 & 7.98 & 168 & 1.96 & 8.59 & 0.65 & 8.89 & 1 \\
\hline $\begin{array}{l}\text { Jiguru } \\
\text { Mare }\end{array}$ & $\begin{array}{l}\text { Comăr- } \\
\text { nicel }\end{array}$ & 967 & 7.92 & 12.22 & 6.02 & 638 & 6.16 & 10.36 & 2.19 & 8.46 & 1 \\
\hline $\begin{array}{l}\text { Comăr- } \\
\text { nicel }\end{array}$ & $\begin{array}{l}\text { Bătrâna } \\
\text { (crest) }\end{array}$ & 206 & 2.31 & 8.92 & 1.36 & 248 & 3.06 & 8.11 & 1.00 & 2.43 & $1 / 4$ \\
\hline $\begin{array}{l}\text { Bătrâna } \\
\text { (crest) }\end{array}$ & $\begin{array}{l}\text { Tâmpu } \\
\text { (crest) }\end{array}$ & 129 & 1.63 & 7.91 & 0.67 & 212 & 2.04 & 10.38 & 0.73 & 1.43 & $1 / 6$ \\
\hline $\begin{array}{l}\text { Tâmpu } \\
\text { (crest) }\end{array}$ & $\begin{array}{l}\text { Şteaua } \\
\text { Mică } \\
\text { (crest) }\end{array}$ & 22 & 0.65 & 3.40 & 0.29 & 37 & 0.74 & 5.02 & 0.22 & 0.52 & $1 / 9$ \\
\hline $\begin{array}{l}\text { Şteaua } \\
\text { Mică } \\
\text { (crest) }\end{array}$ & Muncel & 196 & 2.71 & 7.25 & 1.44 & 287 & 3.68 & 7.81 & 1.18 & 2.70 & $1 / 3$ \\
\hline $\begin{array}{l}\text { Comăr- } \\
\text { nicel }\end{array}$ & Muncel & 553 & 7.29 & 7.58 & 3.35 & 784 & 9.51 & 8.24 & 3.11 & 6.65 & 1 \\
\hline $\begin{array}{l}\text { Şteaua } \\
\text { Mică } \\
\text { (crest) }\end{array}$ & $\begin{array}{l}\text { Dealul } \\
\text { Șesului }\end{array}$ & 22 & 0.41 & 5.43 & 0.23 & 445 & 3.29 & 13.52 & 1.34 & 1.62 & $1 / 5$ \\
\hline $\begin{array}{l}\text { Vf. lui } \\
\text { Pătru }\end{array}$ & $\begin{array}{l}\text { Dealul } \\
\text { Șesului }\end{array}$ & 955 & 10.18 & 9.38 & 3.70 & 1613 & 15.73 & 10.25 & 5.56 & 9.54 & 1 \\
\hline
\end{tabular}

The last mentioned issue in the list above is far from simple. The normal speed for a man is considered to be $5 \mathrm{~km}$ on a flat terrain. The same man will do less if loaded, for instance with at least $30 \mathrm{~kg}$ of equipment (all types, from weapons to kitchenware), as seems the case for Roman militaries. ${ }^{20}$ Those which made the service in army know exactly what that means; the standard marching test in the Romanian army in 1980s was $20 \mathrm{~km}$ 'quick movement' carrying about $20 \mathrm{~kg}$ of equipment, and it was horrifying (true enough, due mainly to the imposed speed, over $5 \mathrm{~km}$ per hour). Making the same in mountains it is obviously still worst. People accustomed with mountain know that the distances are never expressed in $\mathrm{km}$ (which is futile information) but in hours (for average trained travellers). The estimation is performed with the help of two columns not shown here (for layout reasons): the first is calculating the needed time on a flat landscape, dividing the length to $4 \mathrm{~km}$ (the conventional speed for a loaded man), the second is calculating the slow-down effect of the mountainous terrain, depending on declivity. The implemented formula $(1-(\mathrm{x} / 0.3))$, where $\mathrm{x}$ is the declivity, says, in essence, that the speed is mostly null for a declivity of $30^{\circ}$, which is not fully true, but very close. The rest is a calculation of proportions: at declivities up to $15^{\circ}$, the speed would be then about half, but around $80 \%$ on some tracks on the ridge of

\footnotetext{
${ }^{20}$ Some estimates go as high as $45 \mathrm{~kg}$ load for a man (Roth 1999,75 ), which is difficult to take - in our experience no matter the pretended experiments performed in modern times.
} 
the mountain. Easy to observe, the worst routes are those accessing the lower parts of the mountains (both Parâng and Şureanu).

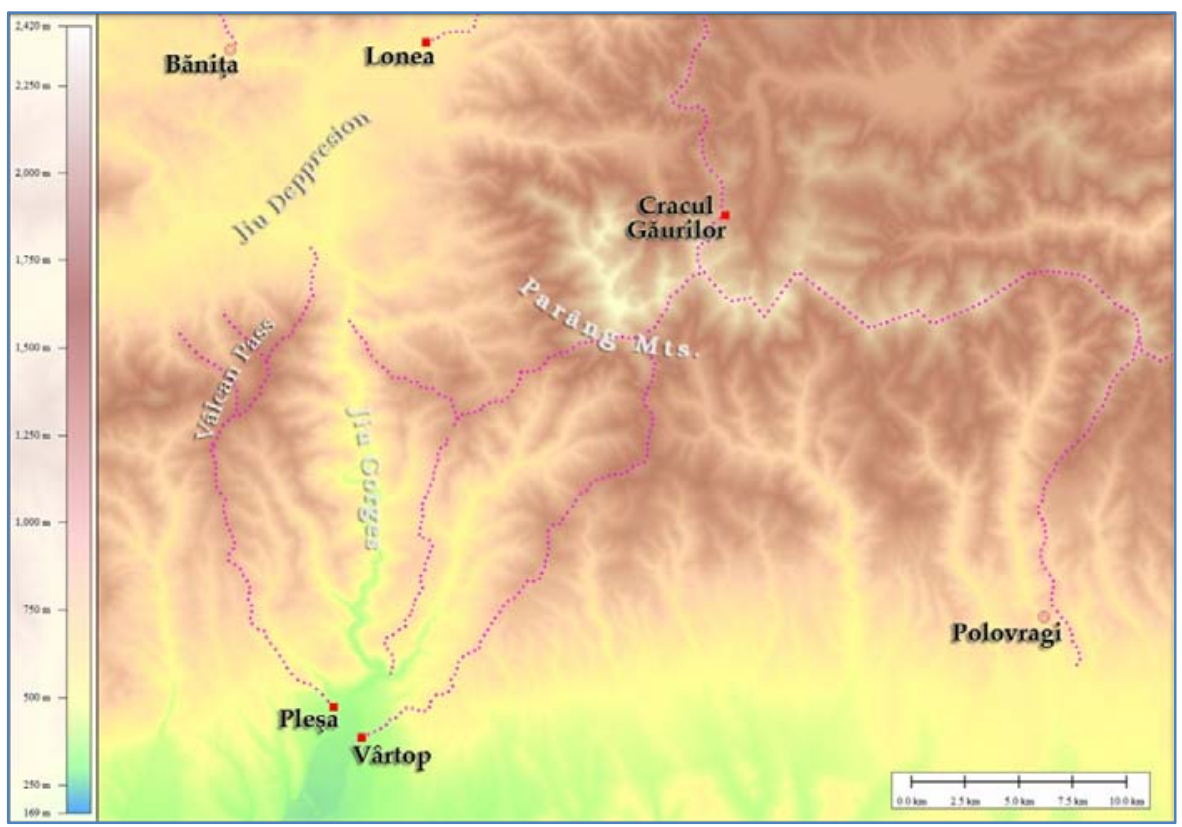

Figure 9.

Parâng Mountains and the main military objectives in the time of the Trajan's wars. SRTM-30 (2018), UTM projection. Legend as at the Figure 1.

Under the label 'descending' one will find the same columns as the previous, except the calculation of slow-down effect, for which the formula is changed in 1-(x/0.35). In fact, the calculation for 'descending' could be the same as for 'ascending', as at least some of the militaries had to make the route in both directions (for instance the logistic caravans).

Under 'total' the calculated hours needed to ascend and descent along the route are summed, adding a $3 \%$. This addition is due to a certain fact: a $30 \mathrm{~m}$ resolution terrain model is obliterating many details of the terrain; a test made on the very surface of the camp at Cracul Găurilor proved that one and the same line is $1.6 \%$ shorter on SRTM (resolution at $30 \mathrm{~m})^{21}$ than on our terrain-model, at the resolution of 0.23 $\mathrm{m}$. In fact, no matter how fine is a terrain-model, there are obvious limits in peaking up the 'ideal' path for a caravan; therefore we have added to the needed time not $1.6 \%$, but $3 \%$.

The 'hours' under 'total' were finally turned to days of march, considering that 8 to 9 hours of march would be top army could do, on a daily basis. One would not forget that a Roman military has not only to walk a long distance each day, but also to pack the camp (the tent, personal goods, arms, etc.), to unpack them and - sometimes at least - to dig the ditches of a new encampment, and all those in a single day, before dark.

On brief, our calculations and final figures (necessary days of march) should be taken as a minimum, because it is difficult to believe that infantry and logistic caravans could make it better. The final results were a bit surprising for ourselves, here and there. For instance, in our expectations the route between Cracul Găurilor and Vârful lui Pătru would be a two days journey, but in fact there are surely at least three. The 'detail' is critical, because the areas where the missing camps could be found are different from case to case. For a change, the distance between Vârtop and Cracul Găurilor is two days, the night stop being expected probably around the peak Molidvișu $(1757.5 \mathrm{~m}){ }^{22}$

\footnotetext{
${ }^{21}$ We are using also Alos Palsar terrain model, much better (resolution $12.5 \mathrm{~m}$ ), but unfortunately it does not cover the whole area in work. For the sake of homogeneity we have used the file which is stretching out all over the area where travel calculation was needed.

${ }^{22}$ Although having good orthophotos for the area, we have not been able so far to find it, but not the whole route is clear of woods.
} 
Speaking of lengths of the vary routes heading Sarmizegetusa Regia, we have to note that the way over Parâng Mountains is not definitely longer than the alternative crossing the Vâlcan Pass. Only for reaching from Oltenia in the Jiu Depression the way is painfully long $(27 \mathrm{~km})$, climbing from $300 \mathrm{~m}$ altitude to $1678 \mathrm{~m}$ (Vâlcan Pass), descending then to $570 \mathrm{~m}$, which is a two days journey. The road to Lonea camp ${ }^{23}$ (estimated to another $15 \mathrm{~km}$ ) would take another day, in an area much closer to the enemy's armed forces. Another two days are necessary to reach Pătru Peak, facing the worst declivity from our table $\left(14.73^{\circ}\right.$ as an average on climbing). To be precise, departing from the mouth of Jiu Gorges, at Vârtop, and going to Vârful lui Pătru trough Parâng Mountains will take also five days. This is clearly illustrating the attempt made by the Romans to find multiple ways of reaching Şureanu crest, which is above the Dacian capital. The strategy behind is simple: if one way is locked by the resistance opposed by the enemy, another one will be unlocked by another military column.

Of course, as long as the middle distance encampment between Vârtop and the one on the crest, at Cracul Găurilor, is not positively know, the route is not secure as a historical certitude. One shouldn't rule out the possibility that the troops encamped at Cracul Găurilor came from east, following the crests of Căpăţanii Mountains, then Parâng. That would mean a far longer journey to reach Şureanu Mountains, but it is not impossible, the traveling conditions along Căpăţânii Mountains being the same as along Şureanu Mountains, far better than expected, mainly on the ridge. At the south-western feet of Căpăţânii Mts. there is an old Dacian fortress, Polovragi, probably in ruins when Trajan has pushed his troops over the Danube. ${ }^{24}$ Yet we do not know any Roman fortifications at the middle way between Jiu Valley and Olt Valley, in order to take advantage of the former Dacian way connecting Polovragi by Sarmizegetusa.

Another about $50 \mathrm{~km}$ east of Polovragi one can find another Dacian fortress, Buridava, near the Olt River. In its proximity, on the river bank, there was a Roman fort, within nowadays village Stolniceni. Older researches in the area recovered stamps left by vexillations of legionaries from I Italica, V Macedonica and XI Claudia, all mobilised from Moesia inferior. For about the same place the so-called Hunt Papyrus mentions parts of cohors I Hispanorum veterana quingenaria as being at Buridavae in vexillatione. ${ }^{25}$ Such a concentration of elite troops is not abnormal south of Carpathians Mountains, being encountered especially in middle northern Muntenia, in forts driving from Danube to the Tatar Pass (as Târgşor and Drajna de Sus), ${ }^{26}$ heading south-eastern Transylvania, ${ }^{27}$ a secondary - but still important - front in the Dacian Wars. Well, then: what was doing such an important task force at Buridava? The Olt gorges was very likely not an option within the war, although some historians still consider it. ${ }^{28}$ As no other mountain

\footnotetext{
${ }^{23}$ Ferenczi 1983, 185, about some consistent Roman remains (pottery, bricks and tiles, some stamped by legio XIII Gemina) found in the neighborhood Lonea from the eastern part of the town Petrila, at the foot of the Mount Capra, supposed rather to bespoke about an early camp than a civilian settlement. Alexandru Stefan $(2005,577)$ name it Campa (correct Cimpa), which is in the close vicinity of Lonea, but here and there some could find also other names, as, for instance, 'Gropile lui Pyrrhus'.

${ }^{24}$ Glodariu 1983, 80-82, considered by many as ruined before the Trajan's wars, but the author has cast doubt. In our view, the simple fact that no Roman camp is known there and nowhere around, makes us go with the majority.

${ }^{25}$ Petolescu 2010, 162-163.

${ }^{26}$ Zahariade, Lichiardopol, 2006, esp. 122. Stamps of those three mentioned legions are spread all over the northern Muntenia, mainly in the pre-mountainous areas, but all of them are present only at Drajna de Sus, which is the last fort before the mountain paths. This might be relevant for the importance of the discoveries from StolniceniBuridava.

27 A completely different explication gave Țentea and Matei Popescu (2016, 61-63), preferring to connect all military structures from northern Muntenia by the reach salt deposits from the area, not by the routes connecting the two sides of the mountains. That was anyway before Dan and Magdalena Ştefan published (2018) their research on the top of the mountains (Siriu) driving to Tatar Pass (sometimes named 'Buzău Pass'), including two Roman temporary encampments.

${ }^{28}$ Petolescu 2010, 139, citing also Constantin and Hadrian Daicoviciu (commenting Cassius Dio LXVIII 9, 4, about Laberius Maximus, the governor of Moesia inferior, which captured Decebalus' sister and a stronghold, either Costeşti or Tilişca, both on the northern frame of the mountains). The fort Arutela, located at the lower entrance in the gorges, was built in 138, as well as Copăceni, further north. The forts from the inner road, bypassing Cozia Mountain on east, as Rădăcineşti and Titeşti, are small and give no hint about the presence of the vexillations coming from Moesia inferior, being most likely built in Hadrian's time. As for the fort closing Olt gorges at the northern end, Caput Stenarum (Boiţa), it is still later, made in the time of Marcus Aurelius (Vlădescu 1983, 92-115). The idea that the Olt gorge was used for military operations within the Dacian wars was repeatedly rejected by archaeologists, as Zahariade, Dvorski 1997, 60 or Glodariu 2004, 539. A similar point of view was recently made
} 
pass exists about $70 \mathrm{~km}$ around Buridava, one has to examine another option: taking the mountain paths towards Sarmizegetusa. ${ }^{29}$ Only a full cover of LiDAR data for the Romania's territory will prove this true or wrong.

\section{CONCLUSIONS}

The Roman encampment from Cracul Găurilor is relatively typical for the Roman camps made around Sarmizegetusa Regia, both as size and layout. What is not exactly the norm is the strong slope on which it was made, being apparently the result of a crisis situation, possibly an imminent clash with the enemy. Its location is a strong suggestion that Romans moved towards the Dacian capital on more than 'traditionally' three columns admitted so far by historians.

Eugen S. Teodor (esteo60ATyahoo.co.uk) is archaeologist at the History National Museum from Bucharest

Aurora Peţan (apetanATgmail.com) is leading Dacica Fundation, Alun, Boşorod, Hunedoara County

Alexandru Hegyi (alexandruhegyiATgmail.com) is GIS specialist and geophysicist at the West University in Timişoara

\section{BIBLIOGRAPHY}

Campbell 2017 Campbell, D., The Roman Army Camp, in Strassler, R.B., Raaflaub, K.A. (eds.), The Landmark Julius Caesar. Web Essays, Pantheon Books: New York, Toronto, 68-73.

Daicoviciu, $\quad$ Daicoviciu, C., Ferenczi, A., Aşezările dacice din Munţii Orăş̧tiei, Ed. Academiei:

Ferenczi, 1951

Bucureşti.

Ferenczi 1983 Ferenczi, Ș., Observații tipologice și comparative la castrele de marș romane situate în zona cetăților dacice din Munții Șurianului, Sargetia, 16-17 (1982-1983), 179198.

Glodariu 1974 Glodariu, I., Itinerarii posibile ale cavaleriei maure în războaiele dacice, in In memoriam Constantini Daicoviciu, Ed. Dacia: Cluj, 151-164.

Glodariu 1983 Glodariu, I., Arhitectura dacilor, civilă şi militară (sec. II î.e.n.-I e.n.), Ed. Dacia: Cluj-Napoca.

Glodariu 2000 La zone de Sarmizegetusa Regia et les guerres de Trajan, Studia Antiqua et Archaeologica, 7, 363-376.

Glodariu 2004 Glodariu, I., Roads across the Carpathians during the Dacian antiquity, Orbis Antiquus. Studia in Honorem Ioannis Pisonis, Nereamia Napocae Press: ClujNapoca, 538-541.

by Țentea, Matei-Popescu 2016, 57-58, saying that the Romans did not go further north of Buridava, within the Dacian wars, although in the same book (idem, 12-13) one will find a map of the forts existing in the time of the conqueror, including those located north of Castra Traiana. There is still one voice claiming the contrary, as an (unsustainable) hypothesis, see Schuster 2013 (a good archaeologist, yet with another specialisation).

${ }^{29}$ The idea is yet not new at all (Stefan 2005, 574, note 124, with literature). 
Gudea 1997

Oltean 2012

Olteanu, Hanson 2017

Petolescu 2010

Roth 1999

Schuster 2013

Stefan 2005

Ştefan, Ştefan, 2018

Teodor 2018

Teodor, Pețan, Berzovan, 2013 a

Teodor, Peţan, Berzovan, 2013 b

Teodor, Pețan, Hegyi 2018

Țentea, MateiPopescu 2016

Vlădescu 1983

Zahariade, Dvorski 1997

Zahariade, Lichiardopol 2006
Gudea, N., Der dakische Limes. Materialien zu seiner Geschichte, Jahrbuch des Römisch Germanischen Zentralmuseums Mainz, 44, 2, 497-609.

Oltean, D., Regii dacilor și războaiele cu romanii, (no publisher): Deva.

Olteanu, I.A., Hanson, S.H., Conquest strategy and political discourse new evidence for the conquest of Dacia from LiDAR analysis at Sarmizegetusa Regia, in Journal of Roman Archaeology, 30, 2017, 430-446.

Petolescu, C.C., Dacia. Un mileniu de istorie, Ed. Academiei Române: București.

Roth, J.P., The Logistics of the Roman Army at War, Brill: Leiden, Boston, Köln.

Schuster, C., Castelul de la Caput Stenarum şi Cohors I Flavia Commagenorum, Terra Sebus, 5, 237-253.

Stefan, A.S., Les guerres daciques de Domitien et de Trajan: architecture militaire, topographie, images et histoire, Collection de l'École française de Rome - 353, École française de Rome: Roma.

Ştefan, D., Ştefan, M., Remote-sensing for Mountain Archaeology in the Curvature Mountains. The fortifications around Crai's Peak, Istros, 24, in press.

Teodor, E.S., Watching and Warning along the Limes Transalutanus. The Search for Watchtowers along its Southern Sector, in Sommer, C.S., Matešić, S. (eds.), Limes XXIII. Proceedings of the 23rd International Congress of Roman Frontier Studies, Ingolstadt 2015, Nünnerich-Asmus Verlag: Mainz, 331-340.

Teodor, E.S., Peţan, A., Berzovan, A., Cercetări perieghetice pe Platforma Luncani. I. Târsa şi Poiana Omului, http://www.esteo.ro/frUnprinted.html.

Teodor, E.S., Peţan, A., Berzovan, A., Cercetări perieghetice pe Platforma Luncani. II. Ponorici și Chiciura, http://www.esteo.ro/frUnprinted.html.

Teodor, E.S., Pețan, A., Hegyi, A., Comments on the Morphology of the Hillfort from Muncel, ArheoVest VI, In Memoriam Marian Gumă, Timişoara, 24 nov. 2018, JATPress Kiadó: Szeged, 683-706.

Țentea, O., Matei-Popescu, F., Between Dacia and Moesia Inferior. The Roman forts in Muntenia under Trajan, (no publisher): București.

Vlădescu, C.M., Armata romană în Dacia Inferior, Ed. Militară: București.

Zahariade, M., Dvorski, T., 1997, The Lower Moesian Army in Northern Wallachia (AD 101-117). An Epigraphical and Historical Study on the Brick and Tile Stamps Found in the Drajna de Sus Roman Fort, The Sylvi Pub. House: Bucharest.

Zahariade, M., Lichiardopol, D., Componenţa şi structura armatei romane în nordul Munteniei, între anii 101-118, in Teodor, E.S., Țentea, O. (ed.), DACIA AVGVSTI PROVINCIA, crearea provinciei, Cetatea de Scaun: Târgovişte, 121-133. 


\section{Lista ilustrațiilor:}

Figura 1. Principalele obiective militare din Munții Șureanu, în vremea războaielor de la începutul sec. II p.Chr. Model teren SRTM-30 (2018), proiecție UTM. Legenda: pătrate roșii - castre de marş; cercuri duble - cetăţi dacice; carouri verzi - alte fortificații dacice; pătrate transparente - alte posibile lucrări de fortificare; linii magenta (roz intens) - drumuri de plai.

Figura 2. Planul castrului de marș de la Cracul Găurilor. Model-teren cu rezoluția de 0,23 m (dronă), reprezentat după valoarea pantelor (nuanţele mai închise pentru pante accentuate). Linii de contur la 5 m. Legenda: linii roșii continue - contur vizibil al șanțului de apărare; linii roșii întrerupte - linii care nu sunt vizibile pe modelul-teren (dar sunt parțial vizibile pe ortofotoplan).

Figura 3. Capătul nordic al castrului de la Cracul Găurilor. Fotografie luată din afara incintei, de la colțul de NE, pe direcția porții de nord, arătând sistemul de fortificație.

Figura 4. Secțiuni topografice prin sistemul de fortificare, arătând starea de conservare, în ordine pentru porțile de est și vest, apoi colțul de NV. Coordonate UTM.

Figura 5. Secțiune topografică longitudinală prin castrul de la Cracul Găurilor, de la nord spre sud. Coordonate UTM.

Figura 6. Reprezentare a pantelor în interiorul și exteriorul castrului de la Cracul Găurilor. Vezi legenda (în grade).

Figura 7. Fotografie luată de pe Muntele Ciobanu (aflat la 2 km spre sud) spre partea frontală a castrului de la Cracul Găurilor.

Figura 8. Profil topografic longitudinal prin castrul de la Comărnicel 1, de la SV (partea frontală) spre NV (partea dorsală), model Alos Palsar (rezoluție 12,5 m).

Figura 9. Munții Parând și principalele obiective militare în epoca lui Traian. Model teren SRTM-30 (2018). Proiecție UTM. Legenda ca la Figura 1.

Tabelul 1. Rute de creastă prin Masivul Parând și partea orientală a Munților Șureanu. 